UDC 661.185.1

\title{
RESULTS OF LABORATORY AND INDUSTRIAL TESTS OF "IKHLAS-1" NANODEMULSIFIER ON "AKKULKA" FIELD AND THE NEW MECHANISM OF DESTRUCTION OF OIL EMULSIONS
}

\author{
T.K.Dashdiyeva \\ Azerbaijan State Oil and Industry University \\ dashdiyev51@gmail.com
}

Received 25.10.2019

Accepted 20.02.2020

\begin{abstract}
The article presents the results of laboratory and industrial tests of the "IKHLAS-1" nanodemulsifier for the "Akkulka" field of the "Tetisaralgaz" LLC of the Republic of Kazakhstan. According to the test results, it was found that the "KHLAS-1" nanodemulsifier under all technological conditions of primary oil preparation shows significant advantages compared to the basic "DMO-86520" demulsifier. Therefore, "IKHLAS-1" was recommended for widespread introduction of the "Akkulka" field at the Group Installation of primary preparation of oil. Implementation results (since October 2017) also confirms the high efficiency of the "IKHLAS-1" nanodemulsifier. The article sets out also a new mechanism for the destruction of oil emulsions.
\end{abstract}

Keywords: nanodemulsifier "IKHLAS-1", oilfield nanotechnology, nanotechnology in oil production, nanotechnology in oil and water preparation, new mechanism for the destruction of oil emulsions.

doi

\section{Introduction}

Before presenting the existing mechanism for the destruction of emulsions, attention should be paid to the type of oil emulsions. Depending on the physicochemical properties of oil, formation water, and also on the conditions for the formation of emulsions, the size of the globules (droplets) of the dispersed phase is in the range of $0.1-100$ microns (or 100-100000 $\mathrm{nm}$ ). According to I.N.Evdokimov and his employees, some of the oil emulsions exist also in the form of nanoemulsions with a globule size of the dispersed phase no more than $100 \mathrm{~nm}$, and the dispersion phase (medium) represents a nanomicellar structure due to asphaltenes [1].

Emulsions with the same size of globules of the dispersed phase belong to monodisperse systems, and with different sizes of globules of the dispersed phase belong to polydisperse systems. From this point of view, oil emulsions belong to polydisperse systems [2, 3]. There are three types of oil emulsions $[4,5]$ :

- reverse emulsion: it is water in oil (W/O). The outer phase or dispersion phase or continuous phase or dispersion medium consists of oil, and the inner phase or dispersed phase consists of coarsely dispersed, macro-, micro- and nanoscale globules (drops) of water. Reverse emulsions are easily diluted with oil;

- direct emulsion: it is oil in water $(\mathrm{O} / \mathrm{W})$. The outer phase or dispersion phase or continuous phase or dispersion medium consists of water, and the inner phase or dispersed phase consists of coarse, macro-, micro- and nanoscale oil globules (droplets). Direct emulsions are easily diluted with water;

- medium emulsion: it is water in oil, oil in water $\mathrm{W} / \mathrm{O} / \mathrm{W}$. The external phase or continuous phase or dispersion phase or dispersion medium consists of oil and water, and the internal phase or dispersed phase consists of coarsely dispersed, macro-, micro- and nanoscale globules (drops) of water and oil. Medium emulsions are easily diluted with oil and water. In addition, we first established that medium emulsions or hard destructible water-oil emulsions (HDWOE) are emulsifiers of reverse and direct emulsions, thereby increasing the concentration and strength of these emulsions.

Formation water in the composition of oil is in free and bound states, the oil in the composition of formation water also is in free and bound states. Reverse and direct emulsions with coarsely dispersed and macrodispersed phases are easily destroyed by settling or with slight 
heating $[2,3]$. An example of similar, disperse systems is the oil emulsion of the "Akkulka" field "TetisAralGaz" LLP RK. Free water and oil are easily separated respectively from the oil and water phases. And bound water and bound oil are the main components of the dispersed phases of micro- and nanoemulsions W/O and $\mathrm{O} / \mathrm{W}$ and for their separation in the form of free water and free oil, the corresponding emulsions must be destroyed. Therefore, the problems of oil purification from formation water and formation water from oil in the conditions of primary oil preparation are literally connected with the possibility of demulsifiers for the complete destruction of all types of oil emulsions. Known demulsifiers are generally capable of breaking reverse emulsions. Therefore, the development and implementation of nanodemulsifiers for the purification of oil from formation water, and formation water from oil is one of the priority areas of oilfield nanotechnology $[5,7]$.

Based on the above brief review of the literature, we can conclude that any mechanism for the destruction of oil emulsions is associated with micro- and nanoemulsions. The existing mechanism for the destruction of oil emulsions refers only to inverse emulsions and is called the phase inversion mechanism [5-11]. The active part of modern demulsifiers mainly consists of nonionic surfactants of the type oxyalkylated (mainly oxyethylene and oxypropylene) block oligomers based on manyatomic alcohols, amines, phenol formaldehydes, epoxies, organosilicon compounds and other non-colloidal surfactants. According to the theory of phase inversion, each representative of the above homological series of nonionic surfactants has a relatively high surface activity and adsorption capacity compared to natural emulsifiers of oil emulsions. Therefore, in accordance with the phase inversion mechanism, inverse emulsions of the $\mathrm{W} / \mathrm{O}$ type under the influence of demulsifiers break up into direct fragile emulsions of the $\mathrm{O} / \mathrm{W}$ type. Due to such phenomena, water, which before the inversion constituted the dispersed phase, after the inversion performs the function of a dispersion medium, and the oil phase, on the contrary, passes from the dispersion medium to the dispersed phase. In this mechanism, the assumption is made that a direct emulsion, which is formed as a result of inversion of phases in the presence of a demulsifier will have less stability, and in fact, the strength of direct emulsions will also depend from the oil colloids, in particular $\mathrm{W} / \mathrm{O} /$ $\mathrm{W}$ or HDWOE, which are emulsifiers for reverse and direct emulsions. Based on these considerations, with the phase inversion mechanism, it is difficult to interpret the whole range of issues around the inversion itself. In addition, it is not clear from this mechanism due to what strength how the molecular adsorption layers (MAL) are destroyed around water globules, and there is no corresponding interpretation if the demulsifier is capable of destroying all types of oil emulsions, oil colloids, including HDWOE. The Russian scientist I.N.Evdokimov, who is one of the founders of the theory of the existence of natural petroleum nanocolloids, experimentally showed the most serious shortcomings of the phase inversion mechanism [9]. Therefore, the development of a new mechanism for the destruction of oil emulsions is also one of the pressing issues of modern oilfield chemistry.

\section{Information about the field}

At the Group Installation (GI) of primary preparation of oil (PPO) "Akkulka" field "TetisAralGaz" LLP RK in the period from 08.14.1726.08.17, joint experimental industrial tests were conducted of the "IKHLAS-1" nanodemulsifier developed by specialists and scientists of "International Oil Services Kazakhstan" LLP, "Mangistaumunaigas" JSC of the Republic of Kazakhstan and Azerbaijan State Oil and Industry University.

The average value of specific consumption for the base demulsifier "DMO-86520" ("Baker Hughes", USA) is $\sim 69.6 \mathrm{~g} / \mathrm{t}$, and the density is $957 \mathrm{~kg} / \mathrm{m}^{3}$. During EIT, violations of the technological regime associated with "IKHLAS"-1 in the process of oil preparation at GI PPO were not detected. Currently, "TetisAralGaz" LLP oil is extracted only from the AKD-01 well. The daily well production rate, according to the latest data, is about 702.4 tons, the water cut of the fluid, also according to the latest laboratory data, is on average 62$63 \%$, the temperature of the fluid at the wellhead is about $74^{\circ} \mathrm{C}$, and in oil and gas separator (OGS) 
the fluid with a demulsifier has an average temperature of $61.6^{\circ} \mathrm{C}$. Water-oil emulsion according to the state of dispersion refers to coarsedispersed emulsions for which the thermodynamic and aggregative stability have minimum values. This is due to the chemical composition of the oil itself. The density of oil is $\sim 804 \mathrm{~kg} / \mathrm{m}^{3}$. The following belong to the main facilities of the GI: demulsifier dosing unit; OGS wich is an initial indicator of the effectiveness of a demulsifier; separation should be maximized, i.e. the volume of wastewater which is sent to the horizontal steel tank (HST) should also be maximum; there are two technological tanks of the RBC-700 type, oil in one reservoir is referred to as oil - production, in another tank - the commercial ol; the structure of the GI facilities also includes 2 fire tanks of the RVS-600 type; reception of marketable oil using automobile oil tankers is carried out at a special site and transportation of marketable oil to the point of delivery is realized also by automobile oil tankers; quality control of oil and water with selected samples is carried out in the testing laboratory GI.

\section{Laboratory test results}

The results of laboratory tests are shown in Table 1. As follows from table 1, on the concentrations of salts of chlorides in oil and oil in formation water, the effectiveness of "IKHLAS$1 "$ is 4.5 and 3.5 times exceeds efficiency of "DMO-86520" respectively.

Basic data on the technology "DMO86520" at the GI "Akkulka" field "TetisAral-

\section{Gas" LLP}

To the basic data on the implementation technology "DMO-86520" at the GI include the following:
- Base technological and analytical data (RVS-700 commercial tank) for primary oil treatment using "DMO-86520" at the GI "TetisAralGas" LLP for the period 13.07.1714.08.17 (Table 2).

The conclusions of Table 2, about the base technology:

-• The daily volume of the flow rate of the demulsifier: $V_{\mathrm{dvd}}=51.13 \mathrm{dm}^{3}$;

- Average daily mass used demulsifier $: \mathrm{m}_{\mathrm{dmd}}=48.931 \mathrm{~kg}$;

-• Average daily well flow rate (ADWFR) for AKD-01: =702.4 t;

- Average Specific consumption of DMO-86520 UR (sr) = 69.6 g/t;

•• Bound water (BW): 0\%;

-* Average concentration of chloride salts (ACChS): $285.8 \mathrm{mg} / \mathrm{dm}^{3}$;

- The database of analytical monitoring of GI with the introduction of "DMO-86520", as well as the results of the EIT, show that the concentration of chloride salts in oil in oil tankers is on average $10-12 \%$ lower than in a commercial tank $\left(\sim 257 \mathrm{mg} / \mathrm{dm}^{3}\right)$; in OGS, approximately, $15 \%$ less than in the oil tanker ( 296 $\left.\mathrm{mg} / \mathrm{dm}^{3}\right)$, and the concentration of chloride salts in VST oil (production) is approximately in the middle of OGS and commercial VST and averages $290 \mathrm{mg} / \mathrm{dm}^{3}$. The listed actual and statistical data on the concentrations of salts in oil in the GI facilities (OGS, VST-700 (production); VST-700 (commercial); oil tankers) were used as basic data to determine the effectiveness of the demulsifier "IKHLAS-1";

- The basic technology data on the concentration of chloride salts in oil (VST-700 commercial) for the period January-July 2017 (Table 3).

Table 1. The results of laboratory tests of the "IKHLAS-1" nanodemulsifier in comparison to the basic demulsifier "DMO-86520"

\begin{tabular}{|c|c|c|c|c|c|c|c|c|c|}
\hline \multicolumn{2}{|c|}{$\begin{array}{l}\text { Specific consumption } \mathrm{S}_{\mathrm{c}} \text {, } \\
\mathrm{g} / \mathrm{t}\end{array}$} & \multicolumn{2}{|c|}{ Formation water, \% } & \multicolumn{2}{|c|}{ Chloride salts, $\mathrm{mg} / \mathrm{dm}^{3}$} & \multirow{2}{*}{$\begin{array}{c}E, \\
\text { at } \\
\text { times }\end{array}$} & \multicolumn{2}{|c|}{$C_{\mathrm{n}}, \mathrm{mg} / \mathrm{dm}^{3}$} & \multirow{2}{*}{$\begin{array}{c}E, \\
\text { at } \\
\text { times }\end{array}$} \\
\hline $\begin{array}{l}\text { "DMO- } \\
86520 "\end{array}$ & "IKHLAS-1" & $\begin{array}{l}\text { "DMO- } \\
86520 "\end{array}$ & "KHLAS-1" & $\begin{array}{l}\text { "DMO- } \\
86520 "\end{array}$ & "KHLAS-1" & & $\begin{array}{l}\text { "DMO- } \\
86520 "\end{array}$ & "IKHLAS-1" & \\
\hline 70 & 70 & 0 & 0 & 285 & 59 & 4.8 & 62 & 24 & 2.6 \\
\hline 60 & 60 & 0 & 0 & 329 & 74 & 4.4 & 70 & 25 & 2.8 \\
\hline 50 & 50 & 0 & 0 & 380 & 83 & 4.5 & 105 & 27 & 3.8 \\
\hline 42 & 42 & 0 & 0 & 422 & 98 & 4.3 & 137 & 28 & 4.9 \\
\hline \multicolumn{4}{|c|}{ the average value } & 354 & 78 & 4.5 & 93.5 & 26 & 3.5 \\
\hline
\end{tabular}

note: $E$ - efficiency; $C_{\text {oil }}-$ oil concentration in a formation water 
Table 2. The basic technological and analytical data during primary oil preparation using "DMO-86520" at the "Akkulka" field of "Tetisaralgaz" LLP for the period 13.07.17-14.08.17

\begin{tabular}{|c|c|c|c|c|c|c|c|c|}
\hline Oil sampling points & $\begin{array}{l}\text { Sampling } \\
\text { date }\end{array}$ & Demulsifier & $\begin{array}{l}\mathrm{V}_{\mathrm{dvd}}, \\
\mathrm{dm}^{3}\end{array}$ & $\begin{array}{c}\mathrm{m}_{\mathrm{dmd}} \\
\mathrm{kg}\end{array}$ & $\begin{array}{c}\text { ADWFR, } \\
\mathrm{t}\end{array}$ & $\begin{array}{l}\mathrm{S}_{\mathrm{c}} \\
\mathrm{g} / \mathrm{t}\end{array}$ & $\begin{array}{c}\mathrm{BW}, \\
\%\end{array}$ & $\begin{array}{l}\mathrm{ACChS} \\
\mathrm{mg} / \mathrm{dm}^{3}\end{array}$ \\
\hline VST-700 (commercial) & 13.07 .17 & "DMO-86520" & 49.17 & 47.055 & 719.9 & 65.3 & 0 & 176.2 \\
\hline VST-700 (commercial) & 14.07 .17 & "DMO-86520" & 50.99 & 48.797 & 718.5 & 67.9 & 0 & 178.7 \\
\hline VST-700 (commercial) & 15.07 .17 & "DMO-86520" & 49.17 & 47.055 & 716.1 & 65.7 & 0 & 183.6 \\
\hline VST-700 (commercial) & 16.07 .17 & "DMO-86520" & 50.99 & 48.797 & 716.5 & 68.1 & 0 & 183.1 \\
\hline VST-700 (commercial) & 17.07 .17 & "DMO-86520" & 49.17 & 47.055 & 713.3 & 65.9 & 0 & 407.2 \\
\hline VST-700 (commercial) & 18.07 .17 & "DMO-86520" & 48.24 & 46.165 & 710.7 & 64.9 & 0 & 351.9 \\
\hline VST-700 (commercial) & 19.07 .17 & "DMO-86520" & 50.99 & 48.797 & 709.0 & 68.8 & 0 & 362.9 \\
\hline VST-700 (commercial) & 20.07 .17 & "DMO-86520" & 56.45 & 54.022 & 708.6 & 76.2 & 0 & 356.2 \\
\hline VST-700 (commercial) & 21.07 .17 & "DMO-86520" & 47.35 & 45.313 & 704.3 & 64.3 & 0 & 382.9 \\
\hline VST-700 (commercial) & 22.07 .17 & "DMO-86520" & 52.81 & 50.539 & 704.5 & 71.7 & 0 & 367.4 \\
\hline VST-700 (commercial) & 23.07 .17 & "DMO-86520" & 49.17 & 47.055 & 701.6 & 67.0 & 0 & 297.6 \\
\hline VST-700 (commercial) & 24.07 .17 & "DMO-86520" & 50.99 & 48.797 & 698.3 & 69.8 & 0 & 303.7 \\
\hline VST-700 (commercial) & 25.07 .17 & "DMO-86520" & 50.99 & 48.797 & 699.7 & 69.7 & 0 & 233.8 \\
\hline VST-700 (commercial) & 26.07 .17 & "DMO-86520" & 49.17 & 47.055 & 700.7 & 67.1 & 0 & 252.1 \\
\hline VST-700 (commercial) & 27.07 .17 & "DMO-86520" & 45.53 & 43.572 & 699.9 & 62.2 & 0 & 270.3 \\
\hline VST-700 (commercial) & 28.07 .17 & "DMO-86520" & 50.99 & 48.797 & 699.5 & 69.7 & 0 & 294.6 \\
\hline VST-700 (commercial) & 29.07 .17 & "DMO-86520" & 50.99 & 48.797 & 697.3 & 69.9 & 0 & 331 \\
\hline VST-700 (commercial) & 30.07 .17 & "DMO-86520" & 52.81 & 50.539 & 698.3 & 72.3 & 0 & 349.3 \\
\hline VST-700 (commercial) & 31.07 .17 & "DMO-86520" & 54.63 & 52.280 & 698.3 & 74.8 & 0 & 337.1 \\
\hline VST-700 (commercial) & 01.08 .17 & "DMO-86520" & 52.81 & 50.539 & 691.6 & 73.0 & - & - \\
\hline VST-700 (commercial) & 02.08 .17 & "DMO-86520" & 52.80 & 50.529 & 691.2 & 73.1 & 0 & 361.3 \\
\hline VST-700 (commercial) & 03.08 .17 & "DMO-86520" & 54.63 & 52.280 & 693.1 & 75.4 & - & - \\
\hline VST-700 (commercial) & 04.08 .17 & "DMO-86520" & 52.81 & 50.539 & 691.4 & 73.0 & 0 & 298.4 \\
\hline VST-700 (commercial) & 05.08 .17 & "DMO-86520" & 52.81 & 50.539 & 692.9 & 72.9 & - & - \\
\hline VST-700 (commercial) & 06.08 .17 & "DMO-86520" & 45.53 & 43.572 & 693.8 & 62.8 & 0 & 295.3 \\
\hline VST-700 (commercial) & 07.08 .17 & "DMO-86520" & 43.70 & 41.820 & 697.3 & 59.9 & 0 & 215.4 \\
\hline VST-700 (commercial) & 08.08 .17 & "DMO-86520" & 54.63 & 52.280 & 703.7 & 74.2 & - & - \\
\hline VST-700 (commercial) & 09.08 .17 & "DMO-86520" & 52.81 & 50.539 & 704.2 & 71.7 & 0 & 251.3 \\
\hline VST-700 (commercial) & 10.08 .17 & "DMO-86520" & 56.45 & 54.022 & 702.1 & 76.9 & - & - \\
\hline VST-700 (commercial) & 11.08 .17 & "DMO-86520" & 52.81 & 50.539 & 700.5 & 72.1 & 0 & 213.1 \\
\hline VST-700 (commercial) & 12.08 .17 & "DMO-86520" & 50.99 & 48.797 & 703.2 & 69.3 & 0 & 185.2 \\
\hline VST-700 (commercial) & 13.08 .17 & "DMO-86520" & 52.81 & 50.539 & 700.4 & 72.1 & 0 & - \\
\hline VST-700 (commercial) & 14.08 .17 & "DMO-86520" & & & 700.3 & & 0 & 278.7 \\
\hline the average value & - & - & 51.13 & 48.931 & 702.4 & 69.6 & $\mathbf{0}$ & 285.8 \\
\hline
\end{tabular}

Based on the data of Table 3, some statistical generalizations have been made:

-• Determination of the dominant concentration limit of chloride salts in oil (VST700 commercial) during the introduction of "DMO-86520" (January-July 2017 Table 4);

-• Table 5 summarizes the data for determining the dominant concentration limit of chloride salts in oil (VST-700 commercial) during the introduction of "DMO-86520" at the GI of the "Akkulka" field "TetisAralGaz" LLP (JanuaryJuly 2017). The conclusions of Table 5:
-. The distribution function of the number of analyzes over the specified limits is generally logical;

-• The dominant chloride salt concentrations for "DMO-86520" are mainly $(75.1 \%)$ in the ranges: $\left(151-200 \mathrm{mg} / \mathrm{dm}^{3}, 26.1 \%\right) ;(201-$ $\left.250 \mathrm{mg} / \mathrm{dm}^{3}, 27.7 \%\right)$; (251-300 $\mathrm{mg} / \mathrm{dm}^{3}$, $21.7 \%)$

-• The maximum concentration of chloride salts for "DMO-86520" is $407 \mathrm{mg} / \mathrm{dm}^{3}$. 
Table 3. Data (2017 january-july) of the basic technology about concentration of chloride salts in oil (VSTcommercial)

\begin{tabular}{|c|c|c|c|c|c|c|c|c|c|c|c|c|c|}
\hline \multicolumn{14}{|c|}{ Concentration of chloride salts in oil (VST-commercial), $\mathrm{mg} / \mathrm{dm}^{3}$} \\
\hline \multicolumn{2}{|c|}{ January } & \multicolumn{2}{|c|}{ February } & \multicolumn{2}{|c|}{ March } & \multicolumn{2}{|c|}{ April } & \multicolumn{2}{|c|}{ May } & \multicolumn{2}{|c|}{ June } & \multicolumn{2}{|c|}{ July } \\
\hline 1 & - & 1 & 284 & 1 & 234 & 1 & - & 1 & - & 1 & - & 1 & 213 \\
\hline 2 & - & 2 & 130 & 2 & 235 & 2 & - & 2 & - & 2 & - & 2 & 198 \\
\hline 3 & - & 3 & 184 & 3 & 195 & 3 & - & 3 & - & 3 & 205 & 3 & 189 \\
\hline 4 & - & 4 & 211 & 4 & - & 4 & - & 4 & - & 4 & 198 & 4 & 190 \\
\hline 5 & - & 5 & - & 5 & 230 & 5 & - & 5 & - & 5 & - & 5 & 194 \\
\hline 6 & 298 & 6 & - & 6 & - & 6 & - & 6 & - & 6 & 273 & 6 & 184 \\
\hline 7 & - & 7 & - & 7 & - & 7 & - & 7 & - & 7 & - & 7 & - \\
\hline 8 & - & 8 & 225 & 8 & - & 8 & 116 & 8 & - & 8 & 167 & 8 & - \\
\hline 9 & - & 9 & - & 9 & - & 9 & 116 & 9 & - & 9 & - & 9 & - \\
\hline 10 & 343 & 10 & 144 & 10 & - & 10 & 102 & 10 & - & 10 & 290 & 10 & - \\
\hline 11 & 268 & 11 & - & 11 & 242 & 11 & 107 & 11 & - & 11 & - & 11 & 282 \\
\hline 12 & 238 & 12 & 133 & 12 & - & 12 & 138 & 12 & - & 12 & - & 12 & 213 \\
\hline 13 & - & 13 & - & 13 & 245 & 13 & 201 & 13 & - & 13 & - & 13 & - \\
\hline 14 & - & 14 & 228 & 14 & - & 14 & 177 & 14 & - & 14 & - & 14 & - \\
\hline 15 & - & 15 & - & 15 & 191 & 15 & 225 & 15 & - & 15 & - & 15 & - \\
\hline 16 & - & 16 & 214 & 16 & - & 16 & 199 & 16 & - & 16 & - & 16 & - \\
\hline 17 & - & 17 & - & 17 & - & 17 & 220 & 17 & - & 17 & 149 & 17 & 407 \\
\hline 18 & - & 18 & - & 18 & 130 & 18 & 216 & 18 & - & 18 & 133 & 18 & 352 \\
\hline 19 & - & 19 & 199 & 19 & - & 19 & 275 & 19 & - & 19 & - & 19 & 363 \\
\hline 20 & - & 20 & - & 20 & 130 & 20 & 253 & 20 & - & 20 & - & 20 & 256 \\
\hline 21 & 234 & 21 & - & 21 & - & 21 & - & 21 & - & 21 & 155 & 21 & 383 \\
\hline 22 & - & 22 & 216 & 22 & - & 22 & - & 22 & - & 22 & - & 22 & 367 \\
\hline 23 & 251 & 23 & - & 23 & - & 23 & - & 23 & - & 23 & 183 & 23 & 298 \\
\hline 24 & 228 & 24 & 224 & 24 & - & 24 & 252 & 24 & - & 24 & 199 & 24 & 304 \\
\hline 25 & 276 & 25 & 244 & 25 & - & 25 & - & 25 & - & 25 & 167 & 25 & 234 \\
\hline 26 & 215 & 26 & - & 26 & - & 26 & - & 26 & - & 26 & 188 & 26 & 252 \\
\hline 27 & 252 & 27 & 263 & 27 & 117 & 27 & - & 27 & - & 27 & - & 27 & 270 \\
\hline 28 & 269 & 28 & 190 & 28 & - & 28 & - & 28 & - & 28 & 229 & 28 & 295 \\
\hline 29 & - & - & - & 29 & - & 29 & 189 & 29 & - & 29 & 195 & 29 & 331 \\
\hline 30 & 285 & - & - & 30 & - & 30 & - & 30 & - & 30 & 174 & 30 & 349 \\
\hline 31 & 190 & - & - & 31 & 188 & - & - & 31 & - & 31 & - & 31 & 337 \\
\hline $\begin{array}{c}\text { the average } \\
\text { value }\end{array}$ & 257 & - & 206 & - & 194 & - & 186 & - & - & - & 194 & - & 281 \\
\hline $\begin{array}{c}\text { total } \\
\text { average }\end{array}$ & & & & & & & 220 & & & & & & \\
\hline
\end{tabular}

Technological and analytical criteria for evaluating the effectiveness of the demulsifier "IKHLAS-1" during the experimental industrial tests (EIT)

The technological criteria for evaluating the effectiveness of the demulsifier "IKHLAS-1", in comparison with the base demulsifier "DMO86520 " were the results of daily measurements of the following parameters:

- Daily consumption $\left(\mathrm{dm}^{3}\right)$ and daily specific consumption of demulsifier, $\mathrm{g} / \mathrm{t}$;

- Bound water in oil for OGS, VST-700 (production); RVS-700 (commercial); automobile oil tankers, \%;

- Volumes of free water in oil: AKD-01;
OGS; VST-700 (production); VST-700 (commercial); automobile oil tankers, \%;

- Concentration of chloride salts $\left(\mathrm{mg} / \mathrm{dm}^{3}\right)$ in oil samples of: OGS, VST-700 (production); VST-700 (commercial); automobile oil tankers, \%;

- Generalized dominant concentration limits of chloride salts in crude oil;

- Data on the volume of formation water allocated at the OGS (meter data);

\section{Results of EIT}

The results of the EIT on the daily consumption of the "IKHLAS-1" nanodemulsifier as compared to the "DMO-86520" are shown in Table 6. 
Table 4. The dominant concentration limit of chloride salts in oil (PBC-commodity) during the basic technology of "DMO-86520" (January-July 2017)

\begin{tabular}{|c|c|c|c|c|c|c|c|}
\hline \multicolumn{8}{|c|}{ The number of concentrations of chloride salts in each limit (January 2017) } \\
\hline $100-150$ & $151-200$ & $201-250$ & $251-300$ & $301-350$ & $351-400$ & $401-500$ & $501-600$ \\
\hline- & $1(7.7 \%)$ & $4(30.8 \%)$ & $7(53.8 \%)$ & $1(7.7 \%)$ & - & - & - \\
\hline \multicolumn{8}{|c|}{ The number of concentrations of chloride salts in each limit (February 2017) } \\
\hline $100-150$ & $151-200$ & $201-250$ & $251-300$ & $301-350$ & $351-400$ & $401-500$ & $501-600$ \\
\hline $3(20 \%)$ & $3(20 \%)$ & $7(46.7 \%)$ & $2(13,3 \%)$ & - & - & - & - \\
\hline \multicolumn{8}{|c|}{ The number of concentrations of chloride salts in each limit (March 2017) } \\
\hline $100-150$ & $151-200$ & $201-250$ & $251-300$ & $301-350$ & $351-400$ & $401-500$ & $501-600$ \\
\hline $3(27.3 \%)$ & $3(27.3 \%)$ & $5(45,4 \%)$ & - & - & - & - & - \\
\hline \multicolumn{8}{|c|}{ The number of concentrations of chloride salts in each limit (April 2017) } \\
\hline $100-150$ & $151-200$ & $201-250$ & $251-300$ & $301-350$ & $351-400$ & $401-500$ & $501-600$ \\
\hline $5(33.3)$ & $3(20 \%)$ & $4(26.7 \%)$ & $3(20 \%)$ & - & - & - & - \\
\hline \multicolumn{8}{|c|}{ The number of concentrations of chloride salts in each limit (May 2017) } \\
\hline $100-150$ & $151-200$ & $201-250$ & $251-300$ & $301-350$ & $351-400$ & $401-500$ & $501-600$ \\
\hline- & - & - & - & - & - & - & - \\
\hline \multicolumn{8}{|c|}{ The number of concentrations of chloride salts in each limit (June 2017) } \\
\hline $100-150$ & $151-200$ & $201-250$ & $251-300$ & $301-350$ & $351-400$ & $401-500$ & $501-600$ \\
\hline $2(13.3)$ & $9(60)$ & $2(13.3)$ & $2(13.4)$ & & & & - \\
\hline \multicolumn{8}{|c|}{ The number of concentrations of chloride salts in each limit (July 2017) } \\
\hline $100-150$ & $151-200$ & $201-250$ & $251-300$ & $301-350$ & $351-400$ & $401-500$ & $501-600$ \\
\hline- & $5(21.7)$ & $3(13)$ & $6(26.1)$ & $4(17.45)$ & $4(17.45)$ & $1(4.3)$ & - \\
\hline
\end{tabular}

Table 5. Summarized data for determining the dominant concentration limit of chloride salts in oil (VST -700 commercial) during the introduction of "DMO-86520" at the GI of the "TetisAralGaz" LLP field (January-July 2017)

\begin{tabular}{|c|c|c|c|c|c|c|c|}
\hline \multicolumn{7}{|c|}{ The number of concentrations of chloride salts in each limit (January-July 2017) } \\
\hline $100-150$ & $151-200$ & $\mathbf{2 0 1}-\mathbf{2 5 0}$ & $251-300$ & $301-350$ & $351-400$ & $401-500$ & $501-600$ \\
\hline $13(14.1 \%)$ & $24(26.1 \%)$ & $\mathbf{2 5 ( 2 7 . 2 \% )}$ & $20(21.8 \%)$ & $5(5.4 \%)$ & $4(4.3 \%)$ & $1(1.1 \%)$ & - \\
\hline
\end{tabular}

Table 6. The results of the EIT of the nanodemulsifier "IKHLAS -1" (14.08.17-28.08.17) in comparison with "DMO$86520 "$

\begin{tabular}{|c|c|c|c|c|c|c|c|c|c|c|c|c|c|}
\hline \multirow[b]{3}{*}{ Date of } & \multirow{3}{*}{  } & \multicolumn{5}{|c|}{ Demulsifier flow rate } & \multirow{3}{*}{ 离 } & \multirow{2}{*}{\multicolumn{2}{|c|}{$\begin{array}{c}\mathrm{S}_{\mathrm{c}} \\
\text { "IKHLAS-1", } \\
\mathrm{g} / \mathrm{t}\end{array}$}} & \multirow{3}{*}{$>>$} & \multirow{3}{*}{ 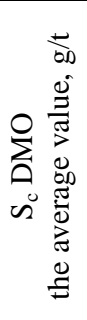 } & \multirow{3}{*}{  } & \multirow{3}{*}{ 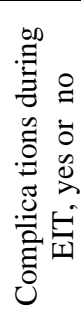 } \\
\hline & & \multicolumn{4}{|c|}{$\mathrm{dm}^{3}$} & \multirow{2}{*}{$\begin{array}{l}\mathrm{kg} \\
\text { fact }\end{array}$} & & & & & & & \\
\hline & & plan & 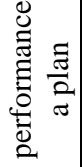 & $\begin{array}{l}\text { reason for non- } \\
\text { fulfillment of } \\
\text { the plan }\end{array}$ & fact & & & plan & fact & & & & \\
\hline 15.08 .17 & 24 & $45 \pm 5$ & + & - & 47.00 & 43.24 & 699.613 & $52.6-65.7$ & 61.8 & 51.13 & 69.6 & 1.13 & no \\
\hline 16.08 .17 & 24 & $45 \pm 5$ & - & $\begin{array}{l}\text { clogging filter } \\
\text { of PAO }\end{array}$ & 25.49 & 23.45 & 699.157 & $52.6-65.8$ & 33.5 & 51.13 & 69.6 & 2.08 & no \\
\hline 17.08 .17 & 24 & $35 \pm 5$ & + & - & 34.60 & 31.83 & 697.380 & $39.6-52.7$ & 45.6 & 51.13 & 69.6 & 1.52 & no \\
\hline 18.08 .17 & 24 & $25 \pm 5$ & - & $\begin{array}{l}\text { clogging filter } \\
\text { of PAO }\end{array}$ & 69.198 & 63.662 & 697.386 & $26.4-39.6$ & 91.2 & 51.13 & 69.6 & FSEP* & no \\
\hline 19.08 .17 & 24 & $35 \pm 5$ & - & $\begin{array}{l}\text { clogging filter } \\
\text { of PAO }\end{array}$ & 52.809 & 48.584 & 681.180 & $40.5-54.0$ & 71.3 & 51.13 & 69.6 & FSEP* & no \\
\hline 20.08 .17 & 24 & $30 \pm 5$ & + & - & 36.420 & 33.536 & 697.671 & $33.0-46.2$ & 48.0 & 51.13 & 69.6 & 1.45 & no \\
\hline 21.08 .17 & 24 & $30 \pm 5$ & + & - & 25.494 & 23.454 & 695.860 & $33.0-46.3$ & 33.7 & 51.13 & 69.6 & 2.06 & no \\
\hline 22.08 .17 & 24 & $30 \pm 5$ & + & - & 30.957 & 28.480 & 690.287 & $33.3-46.6$ & 41.2 & 51.13 & 69.6 & 1.69 & no \\
\hline 23.08 .17 & 24 & $30 \pm 5$ & + & - & 29.136 & 26.805 & 694.555 & $33.1-46.4$ & 38.6 & 51.13 & 69.6 & $1 / 80$ & no \\
\hline 24.08 .17 & 24 & $35 \pm 5$ & + & - & 36.42 & 33.506 & 697.722 & $39.6-52.7$ & 48.0 & 51.13 & 69.6 & 1.45 & no \\
\hline 25.08 .17 & 24 & $35 \pm 5$ & + & - & 38.24 & 35.181 & 695.012 & $39.6-52.7$ & 54.9 & 51.13 & 69.6 & 1.27 & no \\
\hline 26.08 .17 & 24 & $40 \pm 5$ & + & - & 40.00 & 36.800 & 695.214 & $46.3-59.6$ & 52.9 & 51.13 & 69.6 & $1 / 32$ & no \\
\hline
\end{tabular}

note: FSEP* ${ }^{*}$ - fact significantly exceeded the plan 
Comments and conclusions on the data of Table 6.

- On 14.08.17 EIT was started. PAO85327 reagent (against paraffin) was in the tank of the demulsifier dosing unit, but the tank was not cleaned of PAO residues. Further, these residues in the form of deposits were sources of periodic clogging of the metering pump (MP) filter, as a result of which, in the initial period of the EIT (15-19.08.17), the dosage of "IKHLAS-1" was carried out intermittently;

- Monitoring and calculation of daily and specific consumption of the demulsifier is carried out according to the following sequence: plan; registration of facts of fulfillment or nonfulfillment of the plan (+ or - ); reasons for the failure to fulfill the plan; the actual consumption of the demulsifier; daily volume of AKD-01 well fluid $(\mathrm{t})$; calculation of planned and actual specific consumption $\left(S_{\mathrm{c}}\right)$ of the demulsifier; calculation of the effectiveness of "IKHLAS-1" compared to the base demulsifier "DMO-86520";

- As follows from the data of Table 6, during the period 20.08.17-24.08.17, the average daily consumption and specific consumption are $29.156 \mathrm{~kg}$ and $42 \mathrm{~g} / \mathrm{t}$, respectively. At the same time, the minimum specific consumption for "IKHLAS-1" is $33.7 \mathrm{~g} / \mathrm{t}$, that is, 2 times less than the base. This is a very important economic factor in the initial preparation of oil;

- Under all the conditions of the EIT, technological complications have not been observed, on the contrary, significant improvements were established for certain factors of the PPO (more detailed information will be provided in the following comments on the results of the EIT).

The average value of free water in the AKD-01 well's fluid during the EIT month was $58.9 \%$, and during the EIT, it was $60.1 \%$; there is no free water in OGS, VST-700 (commercial), as well as in automobile oil tankers; the average value of free water in the VST-700 (production) during the EIT was 20.6, and for "DMO-86520", it was 39\%. Data on the concentrations of chloride salts in oil samples from OGS, VST-700 facilities (production); VST700 (commercial); automobile oil tankers are shown in Table 7.
Comments and conclusions on Table 7:

- On the concentration of chloride salts in oil samples from OGS, for "IKHLAS-1" is 1.53.0 times less, than for "DMO-86520". In two cases, content of chloride salts (not more than $100 \mathrm{mg} / \mathrm{dm}^{3}$ ) corresponded to the first category of salable oil. Similar results were first discovered for the "IKHLAS-1" nanodemulsifier;

- On the concentration of chloride salts in oil samples from VST-700 (production), for "IKHLAS-1" is 1.9-2.6 times less, than for "DMO-86520";

- On the concentration of chloride salts in oil samples from VST-700 (commercial), for "IKHLAS"-1 is 1.6-2.3 times less, than for "DMO-86520".

Table 8 presents the results of analyzes of the concentration of chloride salts in oil (VST-700 commercial) during the "IKHLAS-1" test at the "Akkulka" field "TetisAralGaz" LLP (08.15.1726.08.17). As follows from Table 8, the dominant concentration limit of chloride salts is the limit of $100-150 \mathrm{mg} / \mathrm{dm}^{3}(92.3 \%)$, and the limit $151-200$ $\mathrm{mg} / \mathrm{dm}^{3}$ accounts for only $7.7 \%$. It should be mentioned that for "DMO-86520" the dominant limits were $151-200 \mathrm{mg} / \mathrm{dm}^{3}$ (26.1\%); 201-250 $\mathrm{mg} / \mathrm{dm}^{3}$ (27.7\%); $251-300 \mathrm{mg} / \mathrm{dm}^{3}(21.7 \%)$, and the limit of $100-150 \mathrm{mg} / \mathrm{dm}^{3}$ accounts for only $14.1 \%$ (Table 5). In this regard, the efficiency of "IKHLAS-1" is 6.5 times higher than that of the base demulsifier "DMO-86520". In general, as shown by the results of EIT, due to "IKHLAS-1", a deeper desalination of oil occurs at all GI facilities. Therefore, "IKHLAS-1", unlike other demulsifiers, including "DMO-86520", for the first time was exhibits a high desalting ability.

The data on the volumes of produced water separated at the OGS (data on the meter) are given in Table 9. As mentioned above, the OGS is an initial indicator of the effectiveness of the demulsifier, in which should be going on the maximum separation of the fluid into phase components, the volumes of wastewater that are sent to the OGS must have maximum values, as evidenced by the data in Table 9 .

The data on the volumes of produced water separated at the OGS (data on the meter) given in Table 9. 
Table 7. The results of comparative analytical monitoring of GI at the "Akkulka" field of "Tetisaralgaz" LLP during the EIT (08.14.17-27.08.17)

\begin{tabular}{|c|c|c|c|c|c|c|c|}
\hline \multirow[b]{2}{*}{ Oil sampling points } & \multirow[b]{2}{*}{$\begin{array}{l}\text { Sampling } \\
\text { date }\end{array}$} & \multirow[b]{2}{*}{$\begin{array}{l}\text { Sampling } \\
\text { time }\end{array}$} & \multirow[b]{2}{*}{ Demulsifier } & \multirow{2}{*}{$\begin{array}{c}\text { Bound } \\
\text { water, } \\
\%\end{array}$} & \multicolumn{3}{|c|}{ Chloride salts, $\mathrm{mg} / \mathrm{dm}^{3}$} \\
\hline & & & & & "IKHLAS-1" & $\begin{array}{c}\text { "DMO-86520" } \\
(13.07-13.08 .17)\end{array}$ & $\begin{array}{l}\text { The effectiveness of } \\
\text { "IKHLAS-1", times }\end{array}$ \\
\hline OGS & 15.08 .17 & $8.00-10.30$ & "IKHLAS"-1 & 0 & 196.0 & 296 & 1.51 \\
\hline VST (production) & 15.08 .17 & $8.00-10.30$ & "IKHLAS"-1 & 0 & 151.0 & 290 & 1.92 \\
\hline VST (commercial) & 15.08 .17 & $8.00-10.30$ & "IKHLAS"-1 & 0 & 147.0 & 286 & 1.94 \\
\hline OTT & 15.08 .17 & $10.30-11.30$ & "IKHLAS"-1 & 0 & 132.0 & 257 & 1.95 \\
\hline OGS & 16.08 .17 & $8.00-10.30$ & "IKHLAS"-1 & 0 & 162 & 296 & 1.83 \\
\hline VST (production) & 16.08 .17 & $8.00-10.30$ & "IKHLAS"-1 & 0 & - & 290 & - \\
\hline VST (commercial) & 16.08 .17 & $8.00-10.30$ & "IKHLAS"-1 & 0 & - & 286 & - \\
\hline OTT & 16.08 .17 & $10.30-11.30$ & "IKHLAS"-1 & 0 & 158 & 257 & 1.63 \\
\hline OGS & 17.08 .17 & $8.00-10.30$ & "IKHLAS"-1 & 0 & 98 & 296 & 3.02 \\
\hline VST (production) & 17.08 .17 & $8.00-10.30$ & "IKHLAS"-1 & 0 & - & 290 & - \\
\hline VST (commercial) & 17.08 .17 & $8.00-10.30$ & "IKHLAS"-1 & 0 & 132 & 286 & 2.16 \\
\hline OTT & 17.08 .17 & $10.30-11.30$ & "IKHLAS"-1 & 0 & 121 & 257 & 2.12 \\
\hline OGS & 18.08 .17 & $8.00-10.30$ & "IKHLAS"-1 & 0 & 143 & 296 & 2.07 \\
\hline VST (production) & 18.08 .17 & $8.00-10.30$ & "IKHLAS"-1 & 0 & 147 & 290 & 1.97 \\
\hline VST (commercial) & 18.08 .17 & $8.00-10.30$ & "IKHLAS"-1 & 0 & 166 & 286 & 1.72 \\
\hline OTT & 18.08 .17 & $10.30-11.30$ & "IKHLAS"-1 & 0 & 140 & 257 & 1.83 \\
\hline OGS & 19.08 .17 & $8.00-10.30$ & "IKHLAS"-1 & 0 & 152 & 296 & 1.95 \\
\hline VST (production) & 19.08 .17 & $8.00-10.30$ & "IKHLAS"-1 & 0 & 141 & 290 & 2.06 \\
\hline VST (commercial) & 19.08 .17 & $8.00-10.30$ & "IKHLAS"-1 & 0 & 149 & 286 & 1.92 \\
\hline OTT & 19.08 .17 & $10.30-11.30$ & "IKHLAS"-1 & 0 & 119 & 257 & 2.16 \\
\hline OGS & 20.08 .17 & $8.00-10.30$ & "IKHLAS"-1 & 0 & 137 & 296 & 2.16 \\
\hline VST (production) & 20.08 .17 & $8.00-10.30$ & "IKHLAS"-1 & 0 & 123 & 290 & 2.36 \\
\hline VST (commercial) & 20.08 .17 & $8.00-10.30$ & "IKHLAS"-1 & 0 & 137 & 286 & 2.09 \\
\hline OTT & 20.08 .17 & $10.30-11.30$ & "IKHLAS"-1 & 0 & 130 & 257 & 1.98 \\
\hline OGS & 21.08 .17 & $8.00-10.30$ & "IKHLAS"-1 & 0 & 140 & 296 & 2.11 \\
\hline VST (production) & 21.08 .17 & $8.00-10.30$ & "IKHLAS"-1 & 0 & 111 & 290 & 2.61 \\
\hline VST (commercial) & 21.08 .17 & $8.00-10.30$ & "IKHLAS"-1 & 0 & 126 & 286 & 2.27 \\
\hline OTT & 21.08 .17 & $10.30-11.30$ & "IKHLAS"-1 & 0 & 100 & 257 & 2.57 \\
\hline OGS & 22.08 .17 & $8.00-10.30$ & "IKHLAS"-1 & 0 & 119 & 296 & 2.49 \\
\hline VST (production) & 22.08 .17 & $8.00-10.30$ & "IKHLAS"-1 & 0 & 126 & 290 & 2.30 \\
\hline VST (commercial) & 22.08 .17 & $8.00-10.30$ & "IKHLAS"-1 & 0 & 123 & 286 & 2.32 \\
\hline OTT & 22.08 .17 & $10.30-11.30$ & "IKHLAS"-1 & 0 & 111 & 257 & 2.31 \\
\hline OGS & 23.08 .17 & $8.00-10.30$ & "IKHLAS"-1 & 0 & 130 & 296 & 2.28 \\
\hline VST (production) & 23.08 .17 & $8.00-10.30$ & "IKHLAS"-1 & 0 & 115 & 290 & 2.52 \\
\hline VST (commercial) & 23.08 .17 & $8.00-10.30$ & "IKHLAS"-1 & 0 & 123 & 286 & 2.32 \\
\hline OTT & 23.08 .17 & $10.30-11.30$ & "IKHLAS"-1 & 0 & 100 & 257 & 2.57 \\
\hline OGS & 24.08 .17 & $8.00-10.30$ & "IKHLAS"-1 & 0 & 134 & 296 & 2.21 \\
\hline VST (production) & 24.08 .17 & $8.00-10.30$ & "IKHLAS"-1 & 0 & 119 & 290 & 2.44 \\
\hline VST (commercial) & 24.08 .17 & $8.00-10.30$ & "IKHLAS"-1 & 0 & 119 & 286 & 2.40 \\
\hline OTT & 24.08 .17 & $10.30-11.30$ & "IKHLAS"-1 & 0 & 107 & 257 & 2.40 \\
\hline OGS & 25.08 .17 & $8.00-10.30$ & "IKHLAS"-1 & 0 & 130 & 296 & 2.28 \\
\hline VST (production) & 25.08 .17 & $8.00-10.30$ & "IKHLAS"-1 & 0 & 108 & 290 & 2.68 \\
\hline VST (commercial) & 25.08 .17 & $8.00-10.30$ & "IKHLAS"-1 & 0 & 130 & 286 & 2.20 \\
\hline OTT & 25.08 .17 & $10.30-11.30$ & "IKHLAS"-1 & 0 & 126 & 257 & 2.04 \\
\hline OGS & 26.08 .17 & $8.00-10.30$ & "IKHLAS"-1 & 0 & 130 & 296 & 2.28 \\
\hline VST (production) & 26.08 .17 & $8.00-10.30$ & "IKHLAS"-1 & 0 & 104 & 290 & 2.79 \\
\hline VST (commercial) & 26.08 .17 & $8.00-10.30$ & "IKHLAS"-1 & 0 & 119 & 286 & 2.40 \\
\hline OTT & 26.08 .17 & $10.30-11.30$ & "IKHLAS"-1 & 0 & 107 & 257 & 2.40 \\
\hline
\end{tabular}

OGS - oil and gas separator; OTT - oil transportation ta"nker; VST - vertical steel tank

Table 8. Determination of the dominant limit of concentrations of chloride salts in oil (PBC-commercial) during the EIT "IKHLAS-1"

\begin{tabular}{|c|c|c|c|c|c|c|c|}
\hline \multicolumn{7}{|c|}{ The number of concentrations of chloride salts in each limit } \\
\hline $100-150$ & $151-200$ & $201-250$ & $251-300$ & $301-350$ & $351-400$ & $401-500$ & $501-600$ \\
\hline $12(92.3 \%)$ & $1(7.7 \%)$ & 0 & 0 & 0 & 0 & 0 & 0 \\
\hline
\end{tabular}


Table 9. Data on the daily volume of formation water $\left(\mathrm{V}_{\mathrm{dvfw}}\right)$ allocated at the OGS (on meter data)

\begin{tabular}{|c|c|c|c|c|}
\hline \multirow{2}{*}{ Date of } & \multirow{2}{*}{ Demulsifier } & \multirow{2}{*}{$\begin{array}{c}\mathrm{V}_{\mathrm{dvfw}} \\
\mathrm{m}^{3}\end{array}$} & \multicolumn{2}{|c|}{ The effectiveness of "IKHLAS" -1 } \\
\hline & & & in $\mathrm{m}^{3}$ & in $\%$ \\
\hline 13.07 .17 & "DMO-86520" & 444.6 & - & - \\
\hline 14.07 .17 & "DMO-86520" & 442.2 & - & - \\
\hline 15.07 .17 & "DMO-86520" & 439.9 & - & - \\
\hline 16.07 .17 & "DMO-86520" & 439.9 & - & - \\
\hline 17.07 .17 & "DMO-86520" & 438.5 & - & - \\
\hline 18.07 .17 & "DMO-86520" & 436.3 & - & - \\
\hline 19.07 .17 & "DMO-86520" & 437.9 & - & - \\
\hline 20.07 .17 & "DMO-86520" & 437.5 & - & - \\
\hline 21.07 .17 & "DMO-86520" & 434.6 & - & - \\
\hline 22.07 .17 & "DMO-86520" & 435.1 & - & - \\
\hline 23.07 .17 & "DMO-86520" & 434.9 & - & - \\
\hline 24.07 .17 & "DMO-86520" & 431.9 & - & - \\
\hline 25.07 .17 & "DMO-86520" & 435.1 & - & - \\
\hline 26.07 .17 & "DMO-86520" & 436.9 & - & - \\
\hline 27.07 .17 & "DMO-86520" & 438.7 & - & - \\
\hline 28.07 .17 & "DMO-86520" & 438.8 & - & - \\
\hline 29.07 .17 & "DMO-86520" & 437.9 & - & - \\
\hline 30.07 .17 & "DMO-86520" & 438.9 & - & - \\
\hline 31.07 .17 & "DMO-86520" & 440.2 & - & - \\
\hline 01.08 .17 & "DMO-86520" & 434.7 & - & - \\
\hline 02.08 .17 & "DMO-86520" & 434.8 & - & - \\
\hline 03.08 .17 & "DMO-86520" & 435.7 & - & - \\
\hline 04.08 .17 & "DMO-86520" & 438.6 & - & - \\
\hline 05.08 .17 & "DMO-86520" & 440.5 & - & - \\
\hline 06.08 .17 & "DMO-86520" & 440.9 & - & - \\
\hline 07.08 .17 & "DMO-86520" & 442.9 & - & - \\
\hline 08.08 .17 & "DMO-86520" & 448.0 & - & - \\
\hline 09.08 .17 & "DMO-86520" & 450.7 & - & - \\
\hline 10.08 .17 & "DMO-86520" & 451.1 & - & - \\
\hline 11.08 .17 & "DMO-86520" & 449.3 & - & - \\
\hline 12.08 .17 & "DMO-86520" & 452.2 & - & - \\
\hline 13.08 .17 & "DMO-86520" & 450.7 & - & - \\
\hline 14.08 .17 & "DMO-86520" + "IKHLAS-1" & 451.3 & - & - \\
\hline the average value & "DMO-86520" & 440.2 & & \\
\hline 15.07 .17 & "IKHLAS-1" & 450.9 & 10.7 & 2.4 \\
\hline 16.07 .17 & "IKHLAS-1" & 450,6 & 10.4 & 2.4 \\
\hline 17.07 .17 & "IKHLAS-1 & 450.6 & 10.4 & 2.4 \\
\hline 18.07 .17 & "IKHLAS-1" & 450.5 & 10.3 & 2.4 \\
\hline 19.07 .17 & "IKHLAS-1" & 441.4 & 1.2 & 0.3 \\
\hline 20.07 .17 & "IKHLAS-1" & 451.8 & 11.6 & 2.6 \\
\hline 21.07 .17 & "IKHLAS-1" & 451.8 & 11.6 & 2.6 \\
\hline 22.07 .17 & "IKHLAS-1" & 448.3 & 8.1 & 1.8 \\
\hline 23.07 .17 & "IKHLAS-1" & 453.0 & 12.8 & 2.9 \\
\hline 24.07 .17 & "IKHLAS-1" & 455.0 & 15.0 & 3.4 \\
\hline 25.07 .17 & "IKHLAS-1" & 455.2 & 15.0 & 3.4 \\
\hline 26.07 .17 & "IKHLAS-1" & 455.6 & 15.4 & 3.5 \\
\hline the average value & "IKHLAS-1" & 451.2 & 11.0 & 2.5 \\
\hline
\end{tabular}

Formation water after sludge from the HST is sent to the reservoir pressure maintenance system. The water volumes during EIT "IKHLAS-1" significantly exceed (by about 11 tons per day, and about 4015 tons per year) compared with "DMO-86520". At the same time, a high degree of wastewater treatment to the level of molecular solubility is achieved, in the conditions of primary oil preparation using the "IKHLAS-1" nanodemulsifier. Therefore, the "IKHLAS-1" nanodemulsifier, unlike other demulsifiers, including "DMO-86520", is are 
universal demulsifier for water-oil (reverse) and oil-water (direct) emulsions.

\section{The mechanism of destruction of oil emulsions}

We found that for highly efficient samples of "IKHLAS" nanodeemulsifiers, the experimental and theoretical maximum adsorption have close values. Therefore, the selection of the most effective demulsifiers from the "IKHLAS" series of nanodeemulsifiers is difficult, that is, it turns out that they all have high adsorption values, and it is difficult to answer the question of which demulsifier will be strong. Therefore, a high adsorption ability for highly effective demulsifiers is a necessary but not sufficient condition. It should be noted that, only on the adsorptions justifications it is difficult to carry out most optimal selection of demulsifiers. Therefore, as the colloid-chemical criteria for assessing the effectiveness of demulsifiers, we first proposed to use the surface pressure $(\pi)$ and also was set the limit value $\pi$ for effective demulsifiers: $\pi \geq 40 \mathrm{~m}$ Дж/ $\mathrm{m}^{2}[5,7]$. Thus, in the new version of the mechanism of destruction of oil emulsions, the decisive value was surface pressure, and the colloidal chemistry of the process is justified by the analogy between the actions of oil-collecting reagents (OCR) and demulsifiers of oil emulsions [5, 7].

- the active phase of the OCR and of demulsifiers mainly consist of nonionic surfactants;

- the main colloid-chemical criterion for evaluating the effectiveness of OCR and demulsifiers is surface pressure (designation of surface pressure for OCR: $\pi_{\mathrm{OCR}}$; for demulsifiers: $\pi_{\mathrm{d}}$ );

- conditions for both reagents: $\pi_{\mathrm{OCR}} \geq 35$

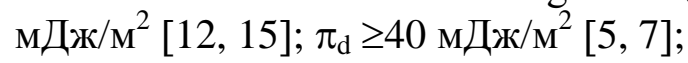

- the basis of modern OCR make up nanoemulsions with a nanomicellar structure [15]; liquid crystalline "IKHLAS" brand nanodemulsifiers (a new hybrid aggregat state of substance) with a double nanostructure (nanomicellar and nanocrystalline structure) are representatives of new generations of demulsifiers [5, 7];

- in both mechanisms of action the interfacial tension $\left(\sigma_{\mathrm{M}}\right)$ decreases to zero, therefore, when measuring $\sigma_{\mathrm{M}}$ on a micrometer stalagmometer according to the UFNII project, is observed the effect of spontaneous separation of a drop from a capillary (SSDFC effect ) [12];

- in both mechanisms of action of OCR and demulsifiers, surface pressure enters as a vectorial value;

- in the case of oil layers based of oil emulsions, the targets of the OCR and demulsifiers are oil emulsions with a fourfold nanostructure [the micellar nanostructure of the dispersion medium due to the micellar structure of asphaltenes; dispersed phase nanoscale globules; nanoscale ring-shaped layers around the globules of the dispersed phase, or molecular adsorption layers (MAL) or a protective shell or an armor shell, the MAL will be more correct, therefore, in subsequent texts it will be advisable to use the term MAL; nanoparticles of organic and inorganic origin inside MAL];

- in both cases, the MAL at the interface between water -air (in the case of OCR) and water-oil or oil-water or water-oil-water (in the case of demulsifiers) is subjected to destructive action by the OCR and demulsifiers;

- in both mechanisms of action of OCR and demulsifiers, the initial phenomenon is competitive adsorption;

- the dialectics of both mechanisms of action is that initial competitive adsorption is a necessary but not sufficient condition for a full assessment of the effectiveness of OCR and demulsifiers. The surface pressure is source of destructive power in relation to the MAL at the phase boundary: water - air; water - oil; oil water; water - oil - water; for the OCR, such a mechanism is generally accepted by experts; to perceive this mechanism for demulsifiers, we continue the scenario with the analogy of the action of the OCR and demulsifiers; it should be noted that the units of measurement of surface tension $(\sigma)$, interfacial tension $\left(\sigma_{\mathrm{m}}\right)$ and surface pressure $(\pi)$ are the same and can be expressed in terms of energy and through forces, for exam$\mathrm{ple}, \mathrm{mJ} / \mathrm{m}^{2}$ and $\mathrm{mN} / \mathrm{m}[13,14]$; to interpret the mechanism of destruction of oil emulsions in analogy with the mechanism of action of the OCR for $\pi$, the expression of the unit of measure in $\mathrm{mN} / \mathrm{m}$ is the most acceptable; in this case, the phrase "surface pressure is the source of the force acting on the MAL"; for the OCR and de- 
mulsifiers becomes quite understandable;

- in both mechanisms of action of OCR and demulsifiers after competitive adsorption, instantaneous competitive spreading of nonionic surfactants at the interface and thereby is occured destruction of MAL; it is at this final stage of the action of the OCR and demulsifiers that, along with the above analogies, are appear also distinctive features of these mechanisms;

- at the final stage of the action of OCR and demulsifiers, it becomes necessary to elucidate the phase of accumulation molecules of functional reagents; for this, three solubility options for OCR and demulsifiers should be considered: option oil-soluble reagents; option water-soluble reagents; option oil-water-soluble reagents; at the final stage, part of oilsoluble OCR is goes into the composition of localized oil, and the other part spreads over the surface of the water. As a result of similar distributions of OCR, is prevented the repeated spreading of localized oil on the water surface. Oil-soluble demulsifiers destroy MAL of reverse emulsions, resulting in the destruction of emulsions and an irreversible process of separation of water and oil and the bulk of the demulsifier goes into the oil phase; in cases of water-soluble OCR and demulsifiers, the bulk of the reagents diffuse into the aqueous phase; it is for this reason that localized oil again spreads over the surface of the water; disadvantages of water-soluble demulsifiers: part of the demulsifier goes into the aqueous phase, resulting in losses reagent and decline efficiency, of the demulsifier ; the destruction of direct, medium emulsions and other types of oil colloids is not achieved, as a result of which the oil concentration in the formation water significantly exceeds the norm of [7,9], and the average emulsion (or HDWOE) and other oil colloids pose an environmental threat to the environment, as well as can create technological complications in the primary preparation of oil;

- naturally oil- and water-soluble OCR and demulsifiers occupy an intermediate position; therefore, oil-solubility it is a necessary quality for highly effective OSR and demulsifiers; on the other hand, the nanostructure of the reagents by both mechanisms of action provides a realistic opportunity for the elimination of the corresponding oil colloids. The maximum reali- zation of these opportunities was achieved for "IKHLAS" brand nanodemulsifiers with a double nanostructure, which were highly effective in conducting numerous industrial tests and introducings at various oil fields of the Republic of Kazakhstan. "IKHLAS" nanodemulsifiers were entered to the regional chemicals market as representatives of a new generation of demulsifiers; all this in aggregate is an unequivocal confirmation of theoretical assumptions, including a new mechanism for the destruction of all types of oil emulsions, with successful results of practicals works; as follows from said abowe new mechanism for the destruction of oil emulsions, the phenomenon of phase inversion does not occur according to the classical theory; based on the new mechanism of destruction of all types of oil emulsions, it can be concluded that "IKHLAS" nanodemulsifiers function also as universal inhibitors of the formation of oil colloids in particular HDWOE in the conditions of PPO.

\section{Conclusion}

Based on the obtained positive results of the EIT, it was concluded "IKHLAS-1" prevails with certain technological, environmental, and economic advantages compared to the base demulsifier "DMO-86520", therefore the acceptance committee of EIT of the nanodemulsifier "IKHLAS-1" as innovations recommended that the for widely introduction at the GI of field "Akkulka" "TetisAralGaz" LLP (with an optimal daily flow rate of $35-40 \mathrm{dm}^{3}$ ). Currently, the "IKHLAS-1" nanodemulsifier is being successfully introduced at six oil fields, including at the field "Akkulka".

\section{References}

1. Evdokimov I.N., Fesan A.A. Multi-step formation of asphaltene colloids in dilutes solutions Colloid and Surfaces A: Physicochemical and Engineering Aspects. 2016. V. 492. P. 170-180.

2. Mirələmov H.F., İsmayılov Q.Q. Neftin, qazın boru kəmərləri ilə nəqli. Bakı: NQETLİ, 2010. $505 \mathrm{~s}$.

3. Levchenko D.N., Bergshtein N.V., Hudakova A.D., Nicolaeva N.M. Emulsii nefti s vodoi i metody ikh razrusheniia. M.: Energoizdat, 1987. $464 \mathrm{~s}$.

4. Pozdnyshev G.N. Stabilizatciia i razrushenie neftianykh emulsii. M.: Nedra, 1982. 224 s.

5. Nugmanov A.K., Gasanov A.A., Dashdiyeva T.K. New hybrid aggregate state of some organic substances and their prospects in oil-field nanotech- 
nology. Int. J. ultidisciplinary Res. Modern Education. 2019. V. 5. ISSUE 1. P. 149-161.

6. Hutorianskii F.M., Akhmadi S., Dosso U., Soltani Bekhnaz. Issledovaniia protcessa obezvozhivaniia i obessolivaniia ochen tiazheloi vysokoviazkoi nefti Verbliuzhego mestorozhdeniia Astrahanskoi oblasti. Mir nefteproduktov. 2015. № 3. C. 10-16.

7. Nugmanov A.K., Dashdiyeva T.K. Surface pressure is one of the main criteria for evaluating the effectiveness of nano demulsifiers for destruction of reverse and direct, emulsions. Int. J. Innovative Res. in Sci. Engineering and Technology. 2019. V. 8. Issue 1. P. 234-242.

8. Borisov S.I., Kateev M.V., Kalinin E.S., Kalinina O.S., Meloshenko N.P., Sorokin V.V. Mehanizm deistviia PAV kak deemulgatorov neftianykh emulsii. http://naukarus.com/mehanizm-deystviyapav-kak-deemulgatorov-neftyanyh-emulsiy.

9. Evdokimov I.N., Losev A.P. Eksperimentalnye dokazatelstva otsutstviia inversii $\mathrm{v}$ promyslovykh vodoneftianykh emulsiiakh. Burenie i neft. 2010. № 5. S. 26-27.

10. Loskunova Iu.V., Iudina N.V., Volkova G.I., Anufrieva R.V. Izuchenie viazkostno- temperatur- nogo povedeniia vodoneftianykh emulsii $\mathrm{v}$ tochke inversii faz. Mezhdunar. zhurn. pricl. i fundament. Issledovanii. 2017. № 10. S. 221-225. https:// applied-research. ru/ru/article/ view?id=11892

11. Grimes B. Population balance model for batch gravity separation of crude oil and water emulsions. Part i: Model formulation. J. Dispersion Science and Technology. 2012. V. 33. No 4. P. 578-590.

12. Gumbatov G.G., Dashdiev R.A. Primenenie PAV dlia likvidatcii avariinykh razlivov nefti na vodnoi poverkhnosti. Baku: Elm, 1998. $210 \mathrm{~s}$.

13. Abramzon A.A., Gaevoi G.M. Poverkhnostnoaktivnye veshchestva. Spravochnik. L.: Himiia, 1979. $376 \mathrm{~s}$.

14. Rusanov A.I., Shchekin A.K., Volkov N.A. Diffuziia $\mathrm{v}$ mitcelliarnykh sistemakh: teoriia i molekuliarnoe modelirovanie. Uspehi himii. 2017. T. 86. № 7. C. 567-588.

15. Dashdiyeva T.K. Selection the nanoemulsions oilcollecting reagents based on adsorbtion studies on the boundary water-air interface. M.Nağıyev adına Kataliz və qeyri-üzvi kimya institutu. Konf. mater. Bakı:15-16 noyabr 2016. S. 214-215.

\section{"İKHLAS-1" NANODEEMULGATORUNUN "AKKULKA" YATAĞINDA LABORATORIYA, SəNAYE SINAQ NOTICOLORI VO NEFT EMULSIYALARININ PARÇALANMA MEXANIZMI}

\section{T.K.Daşdiyeva}

Məqalədə Qazaxıstan Respublikası MMT "Tetisaralgaz" "Akkulka" yatağında "IKHLAS-1" nanodeemulqatorunun laboratoriya və sənaye sınaqlarının nəticələri təqdim olunur. Sınaq nəticələrinə görə müəyyən olunmuşdur ki, neftin ilkin hazırlanmasının bütün texnoloji şərtləri daxilində "IKHLAS-1" nanodeemulqatoru "DMO-86520" baza deemulqatoru ilə müqayisədə əhəmiyyətli dərəcədə üstünlüklərə nalikdir. Ona görə, "İKHLAS-1" "Akkulka" yatağında neftin ilkin hazırlanması üzrə Qruplaşdırılmış Qurğularda geniş miqyasda tətbiq üçün təklif edilmişdir. Tətbiq nəticələri (2017-ci ilin oktyabrından etibarən) "IKHLAS-1" nanodeemulqatorun yüksək səmərəliliyini bir daha təsdiqləyir. Məqalədə neft emulsiyalarının yeni parçalanma mexanizm də şərh edilmişdir.

Açar sözlor: "IKHLAS-1" nanodemulqatoru, neft-mədən nanotexnologiyaları; neftşlxarmada nanotexnologiyalar; neft vo suyun hazırlanmasında nanotexnologiyalar; neft emulsiyalarının yeni parçalanma mexanizmi

\section{РЕЗУЛЬТАТЫ ЛАБОРАТОРНЫХ И ПРОМЫШЛЕННЫХ ИСПЫТАНИЙ НАНОДЕЭМУЛЬГАТОРА "IKHLAS-1" НА МЕСТОРОЖДЕНИИ «АККУЛКА» И МЕХАНИЗМ РАЗРУШЕНИЯ НЕФТЯНЫХ ЭМУЛЬСИЙ}

\section{Т.К.Дашдиева}

Представлены результаты лабораторных и промышленных испытаний нанодеэмульгатора "IKHLAS-1" для месторождения "Аккулка" ТОО "Тетисаралгаз" Республики Казахстан. По результатам испытаний установлено, что нанодеэмульгатор "IKHLAS-1" при всех технологических условиях первичной подготовки нефти показывает значительные преимущества по сравнению с базовым деэмульгатором "ДМО-86520". Поэтому "IKHLAS-1" рекомендован для широкого внедрения на Групповых Установках первичной подготовки нефти месторождения "Аккулка". Результаты внедрения (с октября 2017 г.) также подтверждают высокую эффективность нанодеэмульгатора "IKHLAS-1". Нами предложен также новый механизм разрушения нефтяных эмульсий.

Ключевые слова: нанодеэмульгатор "IKHLAS-1", нефтепромысловые нанотехнологии; нанотехнологии в нефтедобыче; нанотехнологии в подготовке нефти и воды; новый механизм разрушения нефтяных эмульсий. 